The 16th Economic International Conference

New Challenges and Opportunities for the Economy 4.0, May 7-8th, 2020, Suceava, Romania

\title{
The Need for Change and Shaping the Post- COVID Business Environment in Romania
}

\author{
Lucia MOROSAN-DANILA, Otilia-Maria BORDEIANU \\ https://doi.org/10.18662/lumproc/ncoe4.0.2020/35
}

How to cite: Morosan-Danila, L., \& Bordeianu, O.M. (2020). The Need for Change and Shaping the Post-COVID Business Environment in Romania. In C. Nastase (vol. ed.), Lumen Proceedings: Vol. 13. 16th Economic International Conference NCOE 4.02020 (pp. 387-397). Iasi, Romania: LUMEN Publishing House. https://doi.org/10.18662/lumproc/ncoe4.0.2020/35 


\title{
The Need for Change and Shaping the Post-COVID Business Environment in Romania
}

\author{
Lucia MOROSAN-DANILA, Otilia-Maria BORDEIANU² \\ Abstract
}

COVID-19 and the containment policies aimed at controlling it have changed the way people work, the consumer behaviour, forcing most of the businesses to re-configure. During different crisis we have seen many changes, some changes were temporary but also some changes became permanent. Such crises can and will fundamentally reshape our beliefs and behaviours, in terms of our daily lives (at professional and personal level) and economic activities and tendencies. The companies need to prepare for a post-crisis world, rather than waiting for a return to the same conditions in from the past. This paper presents the main changes affecting the business environment today, at European but also national level (focusing on presenting relevant statistics related to the affected companies and fields of activities, the structure of the labour force, level of indebtedness, payment capacity, as well as the associated legal implications) and finally it aims at identifying the practical measures that companies must take to sense, exploit, and re-shape the post-COVID-19 reality. Today, the managers have to find an economically and socially viable path to the next normal.

Keywords: Business environment; COVID-19; containment policies; crisis; labour force.

\footnotetext{
1"Stefan cel Mare" University of Suceava, Romania, lucia.danila@,usm.ro.

2 "Stefan cel Mare" University of Suceava, Romania, otilia.bordeianu@usm.ro. 


\section{Introduction}

According to a statement issued by the European Commission [4], the coronavirus pandemic is a major shock to economies, in the EU and worldwide, with very serious socio-economic consequences. Despite the rapid and comprehensive political response, both at EU and national level, the EU economy will experience a historic recession in 2020.

COVID-19 has affected most countries in the world, regardless of nation, race, social status, financial strength, wealth or poverty. Fear and hysteria maximized the effects of the economic and social crisis, and the population, governments and companies reacted in the most unexpected ways, some by exaggerated measures, even extreme, and others ignoring the situation by continuing life and activities as if the virus did not exist. The question is: who reacted correctly and took the right measures? The reality is reflected in the number of sick people and deaths, the unemployment rate, the number of companies in bankruptcy or which have ceased their activity. Regardless of the situation, time cannot be given back.

\section{Problem Statement}

The outbreak of the COVID-19 pandemic and its global spread created immediate significant societal and economic challenges. Romania is in an ascending state of the epidemic, so all measures must be taken to stop its spread. The 4 stage of COVID-19 spread in Romania involves the minimum travel of the population and companies are obliged to minimise the sped of the virus, in this order searching solutions for sells and telework. In 7 of April, there were 10 Romanian localities in total quarantine, counting a population of 171.980 people. In the same time, 25.379 persons are in institutionalized quarantine and 91.369 people are in isolation at home and under medical supervision [15].

The economic sector was severely affected by COVID-19, like tourism, transport, hospitality, restaurants and non-food commerce. The shock wave will be felt also in other areas. Several government or military ordinances have been issued, through which measures are taken to help and stimulate enterprises in the economic sector.

\section{Research Questions/Aims of the research}

The impact of COVID-19 on the population, countries and economies will be studied and analysed many years from now, being 
perceived as the beginning of a severe economic crisis, from which not everyone will emerge quickly or intact. The repercussions will be felt for a long time, with many countries barely recovering from the 2009 economic crisis [1], [12], [14].

The purpose of the research is to analyse the current situation of Romania (economy and not only) affected by COVID-19 and to identify possible solutions for the economic environment to deal with the pandemic.

\section{Research Methods}

The present research is an exploratory one, involving the analysis of official communications and information published by state institutions related to COVID-19 in fields such as: public health, employability, economic and fiscal legislation, work organization, etc., as well as their impact on the population and companies. The analyses starts from the specific characteristics of the country, starting from the economic, social, cultural, political and regional context [2], [3], [9], [11], [13], [16].

\section{Findings}

COVID-19 and the containment policies aimed at controlling it have changed the way people work and also the consumer behaviour. During different crisis we have seen many changes so we can predict that some changes will be temporary and some changes will become permanent. There have been crises of a social context, having long term consequences in terms of expenditure habits. We can mention SARS crisis in China from 2003 that influenced people's attitude regarding spending: as a big part of the population was frightened to go shopping, many of them redirected to internet commerce. Although the situation wasn't long, a big part of the population sustained online sources later on, stimulating in this sense the platforms like Alibaba and other suppliers.

It is difficult to say exactly how COVID-19 will shape the outlook on society, but it is plausible that we will be able to see a bigger pinpoint (at all levels) on crisis provision, overall preparedness, human support and providing emergency medical assistance. At the individual level, there are also changes, we notice a reconsideration of the way we approach and see the balance between professional life and personal life, trying to analyse what is really important.

The changes observed in this crisis can be seen in extensive changes in many areas, involving commerce, cross-border rules, public health, 
international agreements, business assistance, to cybernetics safety. In the same time, the pandemic influences policy of each affected state, as the population critics the governments' response to such situations.

The Romanian government tried to take preventive measures to support the Romanian economy, in order to avoid collapse. Figure 1 summarizes the implications of the state in dealing with the pandemic, the situation being further detailed.

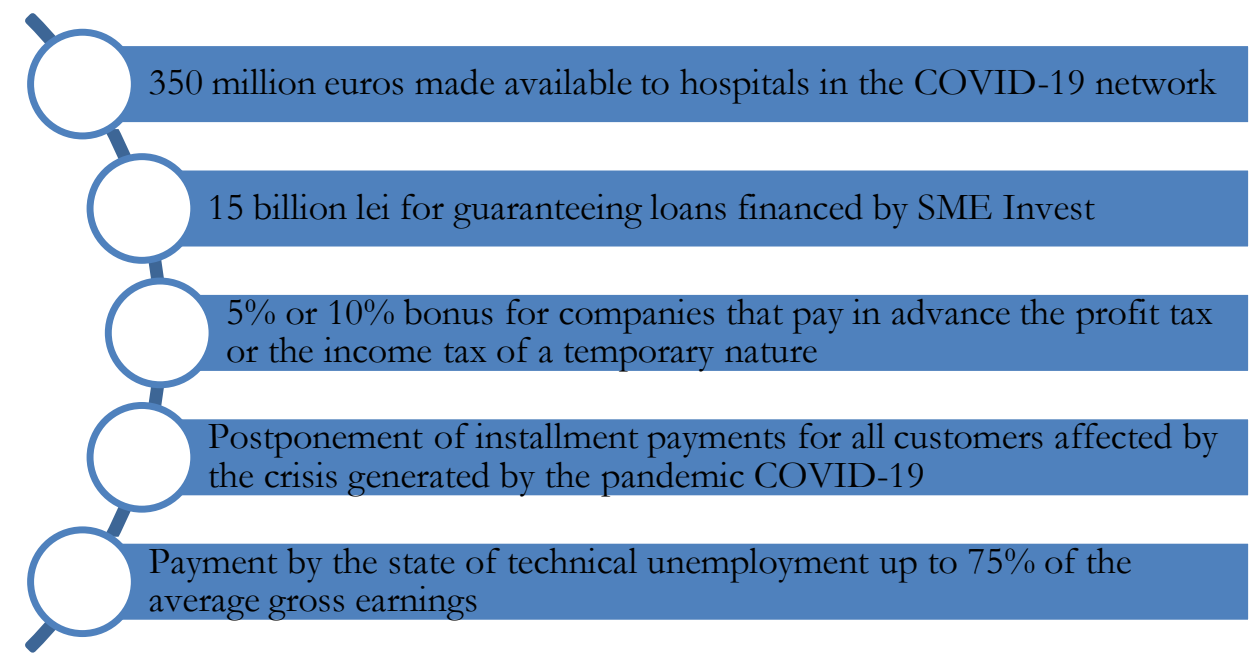

Figure 1. Measures of the Romanian state related to COVID-19

\subsection{Workforce situation}

In the context of COVID-19 pandemic, the number of suspended employment contracts since the beginning of the state of emergency reached, at 30 of March, 1,005,508 units - a situation announced by the Ministry of Labour and Social Protection (MMPS), of which: a number of 314,496 suspended contracts were in the field of manufacturing, another 188,183 were in Wholesale and retail trade / repair of motor vehicles and motorcycles, and 109,861 suspended contracts were in Hotels and restaurants [15].

The employment contracts terminated since the beginning of the state of emergency indicated at 30 of March a number of 240,151, of which: 45,313 were in the fields of Wholesale and retail trade of motor vehicles and motorcycles, 41,891 were in Manufacturing and 32,402 were in Construction. 
The Romanian Government applied the first support for companies by completing the legislation regarding the technical unemployment, so during the state of emergency determined by COVID-19, there are three main normative acts that regulate the situation: Law 53/2003 on the Labour Code (with amendments) [10], although it does not expressly indicate technical unemployment; GEO 30/2020 [6] for amending and supplementing some legislative norms, but also for imposing rules in order to protect the population related to the situation of the pandemic spread of COVID-19 in Romania, that establishes the way in which technical unemployment is applied during the emergency, established by Presidential Decree 195/2020 (until April 16, but the term can be extended, depending on the evolution of the situation on the ground); GEO 32/2020 regarding the amendment and completion of GEO no. 30/2020 [7] for amending and supplementing some legislative norms, but also for imposing rules in order to protect the population related to the situation of the pandemic spread of COVID-19 in Romania, imposing supplementary rules and establishing the procedure by which the state supports technical unemployment benefit.

In the current context, the Government has decided to support all businesses directly or indirectly affected by the state of emergency declared as a result of the COVID-19 epidemic. Thus, by GEO 32/2020, it is specified that the value of the indemnity for technical unemployment, borne by the state, cannot be higher than $75 \%$ of the average gross salary gain, provided by the Law no. 6/2020 regarding the state social security allocation. Therefore, the state pays only the amounts that do not exceed this value. Specifically, the average gross salary is 5,429 lei, which means that the maximum amount granted by the state is 4,071.75 lei.

\subsection{State financing and facilities}

Romanian state has an important public duty, which increased in order to support especially the health system and business environment. The Ministry of Public Finance (MFP) planned, in April 2020, loans from commercial banks of 3.5 billion lei, of which 500 million lei through an issue of discount treasury certificates and 3 billion lei through seven government bond issues, to which can be added the amount of 450 million lei through additional sessions of non-competitive offers, related to bond auctions.

At the same time, the Romanian government is supported by the European Commission through the available non-reimbursable funds. In this sense, the Ministry of European Funds offered 350 million euros to the hospitals in the COVID-19 network, as non-refundable resources, to support their current activities and to buy the necessary equipment related to 
the pandemic. The pandemic has blocked the activities of hospitals around the world, which have to deal with major deficiencies related to emergency equipment and specific respiratory failure, as well as protective and hygiene materials necessary to limit the infection of patients and healthcare professionals.

In April has been launched the program IMM Invest, the largest program to support small and medium enterprises in Romania. This program is granted by the European Commission and gives facility for secured loans for companies for an amount of 800,000 euros per company considered as a program that will restart the economy from now on.

At the same time, the state came with some fiscal facilities for the advance payment of taxes. Taxpayers of income tax payers, regardless of the declaration and payment system, who make payments that are payable for the first three months of 2020, and also transfers made in advance for this months, before the due date of April 25, 2020, receive a bonus of $5 \%$ or $10 \%$, calculated on the profit tax due. Regarding the fees on income tax on micro-enterprises for the months January-March 2020, up to and including 25 April 2020, taxpayers shall receive a 10\% bonus calculated on the tax due for that quarter. Large taxpayers will have a $5 \%$ bonus, while small and medium taxpayers will benefit from a $10 \%$ tax reduction. The provisions also apply accordingly to taxpayers who have opted for a fiscal year other than the calendar year, if they pay the tax due for the quarter / quarterly advance payment by the due date between April 25 and June 25, 2020.

The Ministry of Public Finance has applied to the European Commission for authorization to apply exemptions from customs duties and VAT to imports intended to prevent and combat the spread of COVID-19 [15], such as protective equipment, other medical devices or equipment, medicines, carried out by state organizations, charitable or philanthropic organizations, approved by the competent authorities, or aid agencies / organizations in disaster case. Imported goods will be distributed / made available free of charge to disaster victims, or to meet the needs of preventing, limiting and combating the spread of the COVID-19 outbreak.

\subsection{Consumer behaviour}

The effects of the pandemic can already be seen in our way of working - stimulating and emphasizing work from home, communication through online channels [8], sterilization of the workspace and the way we live.

In this COVID-19 scenario, we see that in Romania online sales increased by 30 percent [5] and this trend will only intensify. This trend is 
sustained by the number of people in quarantine at home, combined with closure of schools and the obligation of parents who have young children to stay at home.

According to estimates by Romanian Association of Online Stores, the e-commerce sector exceeded the threshold of 4.3 billion euros at the end of 2019 , by $20-22 \%$ more than in 2018. Initial estimates for 2020 showed that the value of online purchases will exceed 5 billion euros [16], but in the current situation it is very possible that this value will be even higher.

According to Eurostat, only $23 \%$ of Romania's population made online purchases in 2019, which places us on the penultimate place in the European Union. But there will be new online shoppers (people who did not used online platform for shopping before) that will add significantly to the volume of online sales.

In the same time, there are "significant shock-driven shifts in purchasing patterns in our analysis of activity for hundreds of thousands of consumers" [17]. As a result of the limitation of the possibilities of movement, the food and pharmaceutical field registered sales with over $40 \%$ compared to the pre-pandemic period, also targeting internet sales. On the other hand, travel spending has declined more than $50 \%$.

\section{Discussions}

Permanent changes will not be easy to notice, only through observations and analyses. It is not possible to predict for certainty what changes are liable to be kept, when some companies have already obtained leading positions. The companies that will grow are those that will cope with changing situations; companies which will continuously adapt to the needs of the market and the perceived results by creating new products / processes / strategies, learning and selling intelligently.

Companies may see opportunities by observing fundamental changes in attitude and behaviour and creating mind maps. They will analyse the changes in consumer behaviour (what do we see now? people spending time at home, focusing on hygiene and health and family safety). Changes in the way companies approach activity mat involve work from home, efficient activities, supply diversification opportunities and as well as the increase of the preparation level in front of other economic and social phenomena, similar to this pandemic.

After considering some advices from BCG Henderson Institute and Mckinsey\&Company [17] we emphasize some possibilities that companies can analyze and adapt to their specific needs. Here are 10 steps to consider: 
1. Embrace the changes and try to predict what is to come. Unfortunately, most organizations are isolated when threatened. In fact, we must react to any challenge that is launched, including a pandemic, and try to identify future survival opportunities, but also opportunities. Use everything to your advantage!

2. Be useful. Each company is a component of today's economic and social system. We need more examples of corporate integrity, ingenuity and energy to help fight the crisis.

3. Observe and analyse the changes. Social crises generate new trends in terms of consumer needs, which involves analysing these needs and anticipating the design of new products / services / works, creating new behaviours, adapting the delivery and distribution. For instance, "if leaders' and workers' attitudes toward remote working shift after a few months of experiencing it, that could have significant consequences for office equipment, office real estate, home remodelling, transportation, and other sectors and segments" [17].

4. Analyse data. Companies are encouraged to verify and analyse as many statistical data as possible, which should reflect the trends in the fields of activity, the sales channels used, the increase or decrease of the salary incomes, the crediting level of the individuals and companies. It is extremely important to consider official sources of information, because the pandemic crisis has generated misinformation at all levels.

5. Identify the weak points of your business. "The crisis will undoubtedly expose needs for greater preparedness, resilience, agility, or leanness in different parts of your company." [17] This analysis will help the company to discover its vulnerabilities, but at the same time to find possibilities to overcome them and increase efficiency and effectiveness. Those weaknesses also signal opportunities to reconsider a product or to renew it, to reconsider the company's strategy and respond to faster to the client's needs.

6. Analyse the business environment, as well as the social context, from different regions and countries. Although each has specific features, some patterns can still be created, and the company must adapt and start shaping the future.

7. Scan and replicate the best activity on the market. Small companies and even startups will try to predict the customer needs and observe behavioural patterns. The recommendation is to search and determine how to react to the external environment by replicate some activities. Companies need to investigate opportunities, create an option, replicate and exceed.

8. Avoid unnecessary delays. During crisis a customer may experience unnecessary delays, costs, or other inconveniences. For example many 
companies avoid getting their product online. We should have been consider this aspect before. This type of areas are the ones where other companies started to invent and their success is potentially increased.

9. Sustain the focus on increasing your business. It is hard to be optimistic in this period and there will certainly be further effects of the pandemic, but there is no need to give up and not invest in fear. In all the domains, there have been companies who grew mainly through differential growth (slow growths are the safest). Companies can create new possibilities and attract new investments in different production centres to shape a post crisis future.

10. Activate partnerships. If we learned something about Covid-19 is the fact that no one can prosper alone. We are all part of it, and we need to identify partners and possibilities to cooperate. Business must put partnership at the heart of what it does all the time, not just on specific issues but also on systemic change too. Solidarity it means we can create a 'community of companies' (see NER Group, Spain). This community can be structured in different fields of activity, because the problems and needs are diverse, but with commune points like work force, supplies, imports/exports operations, etc.

If we consider the startups, some sadly won't make it through these challenges that lies ahead, but many will. They are an inspiration and a pointer to us all that a great revolution in business is coming.

\section{Conclusions}

Crises can and will fundamentally reshape our behaviours and beliefs. On the other hand the companies need to prepare and adapt for a post-crisis world, rather than waiting for a return to the same conditions in from the past.

Not all changes will be permanent. Not all trends and needs will remain the same. Sure, some models will return, but certainly not to the same extent. The company must correctly distinguish the trends that go out and identify early those that reappear or adapt [17].

Now we see that some predictions and traditional metrics are somehow irrelevant, so we need more insight to navigate this crisis. It is time to address major questions: what steps to take to overcome crisis?

An idea is suggested by McKinsey Institute (in a suggestion to implement five stages): "Resolve, Resilience, Return, Reimagination, and Reform", so that companies can overcome the crisis generated by COVID19. Specialists offer various solutions to overcome the crisis, all emphasizing 
the importance and role of leaders in the whole process (the main approach for leaders is "trust the unknown"). In times of crisis we can learn that sometimes we do not need a long linear causal plan to succeed. But we need to find an economically and socially viable path to build the company's future.

\section{Acknowledgment}

This work is supported by project POCU 125040, entitled "Development of the tertiary university education to support the economic growth PROGRESSIO", co-financed by the European Social Fund under the Human Capital Operational Program 2014-2020

\section{References}

[1] Boghean C, Boghean F, Nastase C. Morosan-Danila L. Considerations On The Prospects of the Integration of the European Financial Markets in the Context of the Global Crisis. Annals of Faculty of Economics. 2010; 1(2): 509515.

[2] Bordeianu O-.M, Morosan-Danila L. Development and Validation of Research Instruments for Cross-Cultural Studies in Economics and Management, 20h International Economic Conference - IECS 2013, Sibiu, Romania, 2013, pp. 273-279.

[3] Chaşovschi C., Bordeianu O., Clipa D. Entrepreneurial culture in transition economies: The case of Romania and Republic of Moldova. Procedia Economics and Finance, 15, 2014, pp. 1507-1514.

[4] Comisia Europeană. Previziunile economice din primăvara anului 2020: recesiune profundă şi neuniformă, redresare incertă. Available from: https://ec.europa.eu/romania/news/20200506 previziuni economice prima vara ro.

[5] ContentSpeed SRL. Ghid de supravietuire: ce pot face afacerile din Romania ca sa evite criza economica de dupa pandemia COVID-19. Available from: https://doingbusiness.ro/stire/ghid-de-supravietuire-ce-pot-face-afacerile-dinromania-ca-sa-evite-criza-economica-de-dupa-pandemia-covid-19-5008.

[6] GEO 30/2020 for amending and supplementing some normative acts, as well as for establishing measures in the field of social protection in the context of the epidemiological situation determined by the spread of SARS-CoV-2 coronavirus.

[7] GEO 32/2020 regarding the amendment and completion of GEO no. $30 / 2020$ for amending and supplementing some normative acts, as well as for establishing measures in the field of social protection in the context of the 
epidemiological situation determined by the spread of SARS-CoV-2 coronavirus and for establishing additional social protection measures.

[8] Klevtsova M, Polozhentseva Y, Moroşan-Dănilă L. Evaluation of signal indicators of the digital transformation of the Russian economy. The USV Annals of Economics and Public Administration. 2019; 19 (1 (29)): 82-86.

[9] Kyfiak V., Luchyk V., Koroliuk Y., Luchyk S., Losheniuk I., Luchyk M., Korop B., Grygorenko V., Kyfiak O., Slusarciuc M., Morosan Danila L., Nastase C. Forecasting of cross-border regions development: scenario approach. Suceava: Editura Universitatii "Stefan cel Mare"; 2017.

[10] Law 53/2003 on the Labour Code.

[11] Nastase C, Aittaleb Z, Morosan-Danila L. Cultural similarities in service of the cross-border cooperation, between Ukraine and Romania. International scientific and practical conference «Cross-Border Regional Development in the System of Cross-Border Cooperation», 2017, pp. 59-62.

[12] Năstase C., Kajanus M. The impact of the global crisis on SME and entrepreneurship behavior-Romania and Finland cases. Amfiteatru Economic; 3, 2009, pp. 752-753.

[13] Nastase C., Morosan-Danila L. Taxation implications on entrepreneurship in Romania. Proceedings of the Conference "European Choice of Economic Development of the Region", Ukraine; 2016, pp. 94-95.

[14] Năstase C, Popescu M, Scutariu AL. Aspects regarding the global crisis and its impact on tourism industry. Revista Economică; 2011, 475.

[15] National Agency of Press. Available from: https://www.agerpres.ro/.

[16] Olaru A. Creste comertul online. Available from: https://www.rfi.ro/economie-120287-creste-comertul-online-ce-va-facepatronul-de-magazin-de-mall-dupa-criza-covid.

[17] Reeves M, Carlsson-Szlezak P, Whitaker K, Abraham M. Sensing and Shaping the Post-COVID Era, April 3, 2020, BCG Henderson Institute. Available from: $\quad$ https://www.bcg.com/publications/2020/8-ways-companies-canshape-reality-post-covid-19.aspx. 